\title{
Guggulsterone-mediated enhancement of radiosensitivity in human tumor cell lines
}

\section{Rajani Choudhuri, William DeGraff, Janet Gamson, James B. Mitchell* and John A. Cook}

Radiation Biology Branch, Center for Cancer Research, National Cancer Institute, Bethesda, MD, USA

\section{Edited by:}

Zelig Tochner, University of

Pennsylvania, USA

\section{Reviewed by:}

Michael L. Freeman, Vanderbilt

University School of Medicine, USA

Joel S. Greenberger, University of

Pittsburgh Medical Center-Shadyside,

USA

Melissa Ann Fath, University of lowa,

USA

\section{${ }^{*}$ Correspondence:}

James B. Mitchell, Radiation Biology

Branch, National Cancer Institute,

Building 10, Room B3-B69, 9000

Rockville Pike, Bethesda, MD 20892,

USA.

e-mail:jbm@helix.nih.gov
Purpose:To observe the effect of guggulsterone (GS) on the radiation response in human cancer cell lines. Materials and methods: The radiation response of cancer cells treated with GS was observed by cell survival studies, cell growth assay, NF-kB activity assay, western blotting of some key growth promoting receptors, the DNA repair protein $\gamma \mathrm{H} 2 \mathrm{AX}$, and flow cytometry for DNA analyses. Results: GS inhibited radiation induced NF-kB activation and enhanced radiosensitivity in the pancreatic cell line, PC-Sw. It reduced both cell cycle movement and cell growth. GS reduced ER $\alpha$ protein in MCF7 cells and IGF1-R $\beta$ protein in colon cancer cells and pancreatic cancer cells and inhibited DNA double strand break (DSB) repair following radiation. Conclusion: GS induced radiation sensitization may be due to several different mechanisms including the inhibition of NF-KB activation and reductions in IGF1-RB. In addition, GS induced $\gamma \mathrm{H} 2 \mathrm{AX}$ formation, primarily in the S-phase, indicates that DNA DSB's in the S-phase may be another reason for GS induced radiosensitivity. ER $\alpha$ down-regulation in response to GS suggests that it can be of potential use in the treatment of estrogen positive tumors that are resistant to tamoxifen.

Keywords: guggulsterone, radiosensitization, tumor cells, NF-kB activation, cell growth, DNA damage repair

\section{INTRODUCTION}

A major goal in cancer therapy has been to identify drugs that are selectively cytotoxic to tumor cells in order to increase tumor control and lower the toxicity associated with normal tissue damage (Hait and Hambley, 2009; Hambley and Hait, 2009; Ma and Adjei, 2009). Alternatively another approach has been to identify agents, while not curative, may slow or even halt tumor growth over a long period of time, essentially turning cancer into a chronic and manageable disease. For this latter goal there has been renewed interest in natural products that may be less toxic to cells but still have important actions on blocking prosurvival/growth signal transduction pathways. One such natural product is derived from an extract from guggul tree from India containing the compound, guggulsterone (GS; Shishodia et al., 2008). GS is a derivative of the resin of guggul tree Commiphora mukul and has been widely reported as a hypolipidemic agent (Nityanand et al., 1989; Shishodia et al., 2008). Numerous animal and clinical studies have indicated its potential as a therapeutic agent for dyslipidemia (Dixit et al., 1980; Chander et al., 1996). Antagonism of the farnesoid X receptor (FXR) has been suggested as the mechanism for the lipid lowering action of GS (Urizar et al., 2002). It has also been proposed that GS can bind to several steroid receptors at a higher affinity than to FXR (Burris et al., 2005). GS has also been found to activate estrogen receptor alpha (Ero), progesterone receptor (PR), and pregnane X receptor (PXR; Brobst et al., 2004).

Interestingly, GS inhibits activation of NF- $\mathrm{KB}$ and decreases the expression of anti-apoptotic, angiogenic, and metastasis promoting proteins (Shishodia and Aggarwal, 2004; Lv et al., 2008; Xiao and Singh, 2008). GS has been also reported to suppress the constitutive activation of NF- $\mathrm{KB}$ in tumor cells (Shishodia and Aggarwal, 2004). Activation of pro-survival pathways leading to inhibition of apoptosis can have effects on the radiosensitization of cells (Chautard et al., 2010). One such activator or pro-survival pathways is NF- $\mathrm{KB}$ which can be induced by ionizing radiation (IR; Li and Karin, 1998). Given the correlation between NF- $\kappa B$ activation with radiation and inhibition by GS we investigated the effect of GS on the radiosensitivity of human tumor cell lines. GS was found to down-regulate IR-induced activation of $\mathrm{NF}-\mathrm{\kappa B}$ and enhance the radiosensitivity of four human tumor cell lines. Further, GS was shown to inhibit cell growth and inhibit IR-induced DNA damage repair. These findings warrant further research toward evaluation of GS as IR modifier for potential clinical applications.

\section{MATERIALS AND METHODS REAGENTS}

Guggulsterone was obtained from Steraloids, Inc. (Newport, RI, USA) and dissolved in DMSO at a concentration of $25 \mathrm{mM}$. Mouse monoclonal ER alpha and rabbit polyclonal ER beta antibodies were from LabVision Corp. (Fremont, CA, USA); rabbit polyclonal IGF-1R $\beta$, p21 antibodies, and PARP-1 (F-2) were from Santa Cruz Biotechnology, Inc. (Santa Cruz, CA, USA); mouse monoclonal anti-phospho histone H2AX (Ser139), clone JBW301, and rabbit antiserum to histone H2A (acidic patch) were from Upstate Cell Signaling Solutions (Temecula, CA, USA). Mouse anti-actin antibody was purchased from Chemicon Intl. (Temecula, CA, USA). All the HRP linked secondary antibodies were from Santa Cruz Biotechnology, Inc. (Santa Cruz, CA, USA). Goat anti-mouse Alexa Fluor 488 secondary antibody was purchased from Invitrogen (Carlsbad, CA, USA). 


\section{CELL SURVIVAL STUDIES}

HT29 (human colon carcinoma), MCF7 (human breast carcinoma), MIA PaCa-2 (human pancreatic carcinoma), and Bx-PC3 (human pancreatic carcinoma) cells were obtained from American Type Culture Collection (Rockville, MD, USA). PC-Sw (human pancreatic adenocarcinoma) cells were obtained from Dr. William Sindelar (Liebmann et al., 1994). All cell lines were grown in RPMI 1640 supplemented with 10\% fetal bovine serum, 100 units/ml penicillin and $50 \mu \mathrm{g} / \mathrm{ml}$ streptomycin. Stock cultures of cells were maintained in exponential growth in an incubator at $37^{\circ} \mathrm{C}$ in a humidified atmosphere of $95 \%$ air and $5 \% \mathrm{CO}_{2}$.

For cell survival studies, cells were plated $\left(5 \times 10^{5}\right.$ cells $/ 100 \mathrm{~mm}$ culture dishes) and incubated for $16 \mathrm{~h}$ at $37^{\circ} \mathrm{C}$. GS was added to the exponentially growing cells $24 \mathrm{~h}$ prior to IR. A range of IR doses was delivered to cell samples using an Eldorado 8 cobalt-60 teletherapy unit (Theratronics International Ltd. Kanata, ON, Canada) at dose rates of 2.0-2.5 Gy/min. Vehicle control radiation survival curves were conducted in parallel. Twenty-four hours after IR and drug treatment, cells were trypsinized, counted, plated, and incubated for 10-14 days. Colonies were fixed with methanol/acetic acid (3:1) and stained with crystal violet. Colonies with $>50$ cells were scored and cell survival determined after correcting for the plating efficiency and for GS cytotoxicity alone. Survival curve data were fit using a linear-quadratic model according to Albright (1987). Survival curves for each cell were repeated 2-3 times. The dose modification factor (DMF) was determined by taking the ratio of IR doses at the $10 \%$ survival level (control IR dose divided by the GS-treated IR dose). DMF values $>1$ indicate enhancement of radiosensitivity.

\section{CELL GROWTH ASSAY}

Cells $\left(6 \times 10^{4}\right)$ were plated in $60 \mathrm{~mm}$ Petri dishes and incubated overnight. The next day 10, 25, and $50 \mu \mathrm{M} Z$-guggulsterone was added to the dishes (triplicate). After $120 \mathrm{~h}$ the cells were trypsinized with $0.05 \%$ Trypsin-EDTA from Gibco (Carlsbad, CA, USA) and counted.

\section{NF-kB ACTIVITY ASSAY}

Nuclear extracts were prepared (Active Motif, Carlsbad, CA, USA) from HT29 and PC-Sw cells that were either (a) irradiated, or (b) treated with 50 or $100 \mu \mathrm{M}$ GS for $24 \mathrm{~h}$, or (c) pre-treated for $24 \mathrm{~h}$ with 50 or $100 \mu \mathrm{M}$ GS and then irradiated. NF- $\kappa \mathrm{B}$ p50 and p65 transcription factor activity assays were carried out using the TransAM ${ }^{\mathrm{TM}}$ NF- $\kappa \mathrm{B}$ family transcription factor assay kit (Active Motif, Carlsbad, CA, USA).

\section{WESTERN BLOTTING}

Cells $\left(1 \times 10^{6}\right)$ were plated in $100 \mathrm{~mm}$ Petri dishes. GS at various concentrations was added to the cells the following day. Twenty-four hours later some of the Petri dishes were irradiated with a single dose of 6 Gy. The next day all the samples were rinsed with cold PBS and the cells lysed in RIPA buffer (Santa Cruz Biotechnology, Inc. Santa Cruz, CA, USA). The samples were centrifuged at $14000 \mathrm{rpm}$ in a refrigerated centrifuge and the supernatant collected. The samples were kept at $4^{\circ} \mathrm{C}$ if used on the same day or frozen at $-70^{\circ} \mathrm{C}$ for storage. Protein concentration was determined with DC Protein Assay kit (Bio-Rad). Forty micrograms of protein was separated on Tris-Glycine gels (Invitrogen, Carlsbad, CA, USA) and transferred to nitrocellulose membrane using iBlot Dry Blotting System from
Invitrogen (Carlsbad, CA, USA). Non-specific protein binding was blocked by incubating the membranes for $1 \mathrm{~h}$ in $3 \%$ blocking grade non-fat dry milk (Bio-Rad, Hercules, CA, USA) in TBST. The membranes were then left overnight at $4^{\circ} \mathrm{C}$ in the primary antibody at dilution of 1:100 for $E R \alpha ; 1: 200$ for $E R \beta$, IGF-1R $\beta$, p21, and 1:5000 for anti-actin. The membranes were washed thrice in TBST and incubated for $1 \mathrm{~h}$ in horseradish peroxidase conjugated secondary antibody at a dilution of 1:2000 except for actin where the secondary antibody was used at a dilution of 1:10000. The proteins were then visualized by chemiluminescence (Perkin Elmer, Waltham, MA, USA) using Fluor Chem SP imager (Alpha Innotech, San Leandro, CA, USA).

For the determination of phosphohistone H2AX the cells were harvested and frozen at $-70^{\circ} \mathrm{C}$. The samples were thawed on ice and incubated on ice for $10 \mathrm{~min}$ in four volumes of lysis buffer $(10 \mathrm{mM}$ HEPES pH 7.9, $1.5 \mathrm{mM} \mathrm{MgCl}_{2}, 10 \mathrm{mM} \mathrm{KCl}$ with $0.5 \mathrm{mM} \mathrm{DTT}$, and $1.5 \mathrm{mM}$ PMSF). The samples were centrifuged at $14000 \mathrm{rpm}$ for $10 \mathrm{~min}$ in a refrigerated centrifuge. The supernatant was aspirated and the pellet was incubated on ice with $0.2 \mathrm{M} \mathrm{H}_{2} \mathrm{SO}_{4}$ for $4 \mathrm{~h}$. The samples were centrifuged at $14000 \mathrm{rpm}$ for $10 \mathrm{~min}$ at $4^{\circ} \mathrm{C}$. The supernatant (acid soluble histones) was saved and nine volumes of ice cold acetone were added. The samples were kept overnight at $-20^{\circ} \mathrm{C}$. After centrifugation at $4^{\circ} \mathrm{C}$ the pellet was re-suspended in $4 \mathrm{M}$ urea, protein estimated, and $20 \mu \mathrm{g}$ of acid extracted protein run on $18 \%$ gels. Following transfer non-specific binding was blocked by incubating the membranes in 3\% milk in TBST for $1 \mathrm{~h}$ and incubated overnight at $4^{\circ} \mathrm{C}$ in 1:10000 anti-phosphohistone H2AX antibody. The membranes were washed in TBST, incubated for $1 \mathrm{~h}$ in secondary antibody and visualized by chemiluminescence. The membranes were then stripped using Re-Blot Plus mild antibody stripping solution (Chemicon Int. Temecula, CA, USA) and re-probed with an $\mathrm{H} 2 \mathrm{~A}$ antibody for equal loading verification. Densitometric analysis of protein bands was accomplished with image analyzer software coupled with the Fluorchem FC800 system (Alpha Innotech, San Leandro, CA, USA). Density values for each protein were normalized to actin or other control protein values. All westerns were repeated 2-3 times and normalized against actin (in the case of Er $\alpha, E R \beta, I G F-1 R \beta, p 21$ ). The H2AX experiments were repeated twice and normalized against $\mathrm{H} 2 \mathrm{~A}$.

\section{FLOW CYTOMETRY}

Cell cycle analysis was conducted using $1 \times 10^{6}$ cells plated in $100 \mathrm{~mm}$ Petri dishes. The cells were either: (a) treated with GS $(50 \mu \mathrm{M}),(\mathrm{b})$ IR (7 Gy), or (c) treated with GS for $24 \mathrm{~h}$ and irradiated. After $24 \mathrm{~h}$ of incubation the cells were washed with PBS, trypsinized, fixed in cold $70 \%$ ethanol diluted in HBSS and stored at $4^{\circ} \mathrm{C}$. Solutions were brought to room temperature and cells were centrifuged at $1000 \mathrm{rpm}$ for $5 \mathrm{~min}$ and the supernatant discarded. The pellet was washed once in cold PBS and suspended in $1 \mathrm{ml}$ of $20 \mu \mathrm{g} / \mathrm{ml}$ of propidium iodide solution containing $0.1 \%$ Triton X-100 and 500 ng of DNase free RNase. The cells were immediately analyzed for cell cycle changes. All flow experiments were repeated twice.

For $\gamma \mathrm{H} 2 \mathrm{AX}$ studies cells $\left(10^{6}\right)$ were plated in $100 \mathrm{~mm}$ Petri dishes and following various treatments were fixed in $70 \%$ ethanol diluted in HBSS and stored at $4^{\circ} \mathrm{C}$. The cells were then centrifuged at $1000 \mathrm{rpm}$ for $5 \mathrm{~min}$ in a refrigerated centrifuge and the supernatant aspirated. The pellets were suspended in $1 \mathrm{ml}$ of 
cold TST (TBS $+4 \%$ FBS $+0.1 \%$ Triton X-100) and left on ice for $10 \mathrm{~min}$. After centrifugation the supernatant was discarded and the cells were incubated on a shaker for $2 \mathrm{~h}$ at $4^{\circ} \mathrm{C}$ in $200 \mu \mathrm{l}$ of 1:500 anti-phosphohistone H2AX antibody diluted in TST. The cells were then rinsed with TST and incubated on a shaker at room temperature for $1 \mathrm{~h}$ in $200 \mu \mathrm{l}$ of 1:200 secondary antibody (Alexa 488 goat anti-mouse IgG). The cells were rinsed with cold TBS and $5 \mu \mathrm{g} / \mathrm{ml}$ of propidium iodide in cold TBS was added to the cells. Both samples for DNA analysis and $\gamma \mathrm{H} 2 \mathrm{AX}$ studies were analyzed using a BD FACS Calibur (BD Biosciences, San Jose, CA, USA).

\section{STATISTICAL METHODS}

Experiments were repeated 2-3 times and means and SD determined. Student's $t$-test was used to determine the significance of p-values indicated.

\section{RESULTS}

\section{CELL GROWTH AND CELL CYCLE EFFECTS}

Given the reported activation by GS of the various hormone receptors (Brobst et al., 2004) we initially set out to determine if GS would alter cell growth in the estrogen responsive breast cell line, MCF7. Figure 1A demonstrates that incubating MCF7 cells with $10 \mu \mathrm{M}$ GS up to $120 \mathrm{~h}$ reduced cell growth by approximately $60 \%$. Figures 1B,C shows the effect of various concentrations of GS on two other tumor cell lines, HT29, and PC-Sw cells after $120 \mathrm{~h}$ of growth. There was little effect of $10 \mu \mathrm{M}$ GS on PC-Sw cell growth, however, this concentration did reduce growth in HT29 by $35 \%$. Greater growth inhibition was achieved using 25 and $50 \mu \mathrm{M}$ GS, such that $50 \mu \mathrm{M}$ GS incubation reduced growth by greater than $70 \%$ in all three cell lines ( $p<0.05$ for all three cell lines). Clonogenic survival studies indicated that the growth inhibition
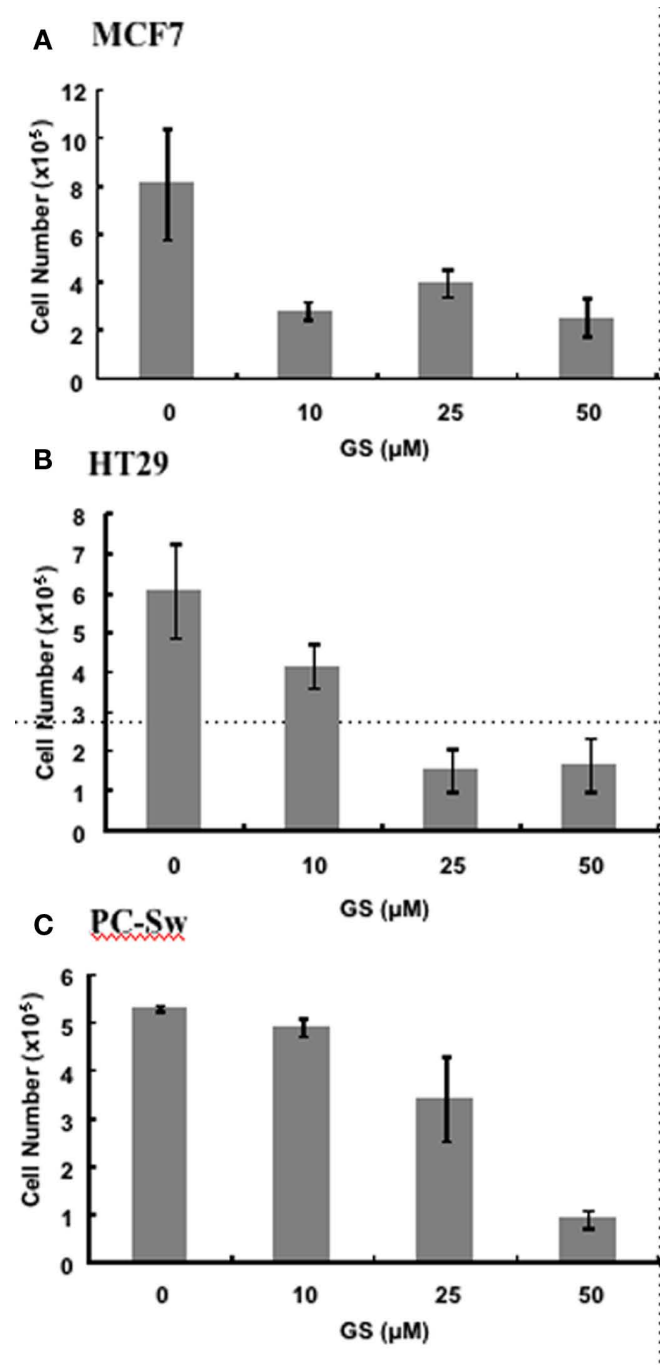

FIGURE 1 | Effect of GS on cell growth and cell cycle movement. Cell growth measurements for (A) MCF7 cells, (B) HT29 cells, and (C) PC-Sw cells incubated with $0,10,25$, or $50 \mu \mathrm{M}$ GS over a 5 -day period. Cells were plated initially at $2 \times 10^{5}$ and counted after 5 days of growth. Flow cytometry study of PC-Sw cells treated either with 6 Gy of IR or treated with $50 \mu \mathrm{M}$ GS for $24 \mathrm{~h}$
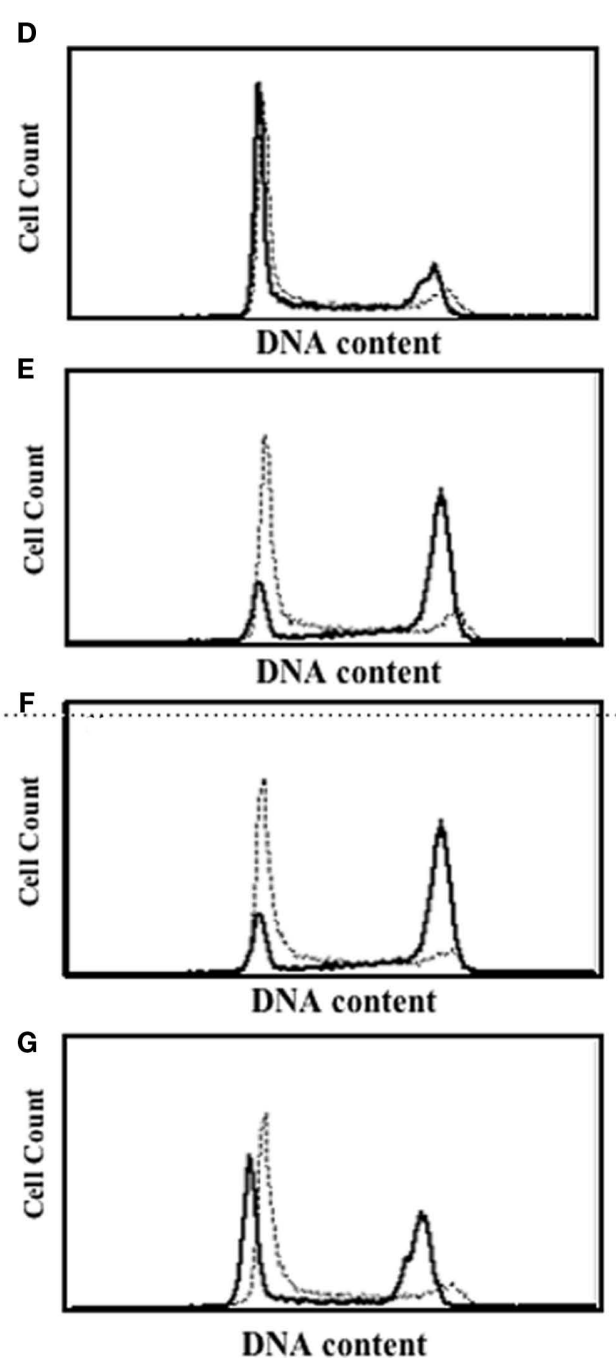

followed by 6 Gy IR. (D) untreated PC-Sw cells (solid line) vs $24 \mathrm{~h}$ GS-treated PC-Sw cells (dotted line). (E) $6 \mathrm{~h}$ post-IR (solid line) vs $6 \mathrm{~h}$ post-IR $+50 \mu \mathrm{M} \mathrm{GS}$ (dotted line) cells, (F) $12 \mathrm{~h}$ post-IR (solid line) vs $12 \mathrm{~h}$ post-IR $+50 \mu \mathrm{M}$ GS (dotted line) cells, (G) $18 \mathrm{~h}$ post-IR (solid line) vs $18 \mathrm{~h}$ post-IR vs $18 \mathrm{~h}$ post-IR $+50 \mu \mathrm{M}$ GS (dotted line) cells. 
found was not due to GS toxicity as $50 \mu \mathrm{M}$ GS incubation showed minimal toxicity on the MCF7, HT29, or the PC-Sw cells (Table 1). Given the growth inhibitory effects of GS, studies were conducted to determine if the GS induced growth inhibition lead to altered cell cycle distribution. As seen in Figure 1D $50 \mu \mathrm{M}$ GS incubation alone in PC-Sw cells did alter the cell cycle distribution after $24 \mathrm{~h}$ incubation (\%G1 increased from 34 to $51, \% \mathrm{~S}$ decreased from 44 to 36 , and $\% \mathrm{G} 2 / \mathrm{M}$ decreased from 22 to 12 ; Figure 1D). To determine if GS was inhibiting cell cycle movement, PC-Sw cells were irradiated with 6 Gy (with or without GS pre-treatment), after which cell cycle movement was followed for $18 \mathrm{~h}$ post-IR exposure. For IR treatment alone cells quickly moved out of G1 (decreased from 20 to $8 \%$ ) into $\mathrm{S}$ and blocked at the G2/M border (increased from 22 to $44 \%$ ) 6 h post-treatment (Figure 1E). By $12 \mathrm{~h}$ cells continued to leave S-phase and block in G2 (Figure 1F), and by $18 \mathrm{~h}$ had moved through the G2/M block as G1 increased from 16 to $58 \%$ (Figure 1G). In contrast, cells pre-treated for $24 \mathrm{~h}$ with $50 \mu \mathrm{M}$ GS followed by IR showed no cell cycle movement over the entire time course examined [\%G1 $(52 \%$ at $3 \mathrm{~h}-54 \%$ at $18 \mathrm{~h}), \% \mathrm{~S}(40 \%$ at $3 \mathrm{~h}-41 \%$ at $18 \mathrm{~h}), \% \mathrm{G} 2 / \mathrm{M}(8 \%$ at $3 \mathrm{~h}-5 \%$ at $18 \mathrm{~h})$ ]. Thus, GS treatment completely blocked cell movement in all phases of the cell cycle following an exposure to IR.

\section{EFFECTS ON GROWTH FACTOR RECEPTORS}

Because of the profound effect of GS on the cell growth experiments were conducted to determine what effect GS incubation was having on various growth factor receptors in these cells. Changes in three growth factor receptors, $\mathrm{ER} \alpha, \mathrm{ER} \beta$, and IGF-1R $\beta$ were analyzed after $24 \mathrm{~h}$ GS incubation alone or in combination with IR in MCF7 cells. IR alone elevated ER $\alpha$ expression, while GS alone at both concentrations substantially down-regulated ER $\alpha$ protein levels (Figure 2A). Likewise, ER $\alpha$ expression was inhibited with the combination of IR and GS (Figure 2A). GS did not significantly affect either ER $\beta$ Figure 3A nor IGF-1R $\beta$ levels in the MCF7 cells (Figure 2B) with any of the treatment combinations. Both the HT29 cells and PC-Sw cells tested negative for the Ero receptor (data not shown); however, Figure 2B shows that IGF-1R $\beta$ was down-regulated by $24 \mathrm{~h}$ incubation with 50 or $100 \mu \mathrm{M} \mathrm{GS}(70-80 \%$ reduction). IR treatment alone showed little effect on IGR-1R $\beta$ in these cells, while the combination of IR and GS was similar for GS alone treatment.

Table 1 | Guggulsterone cytotoxicity alone and IR dose modification factors.

\begin{tabular}{llllll}
\hline Cell Line & \multicolumn{2}{c}{ GS Survival Alone (\%) } & & \multicolumn{2}{c}{ DMF* } \\
\cline { 2 - 3 } \cline { 5 - 6 } & $\mathbf{5 0} \boldsymbol{\mu M}$ & $\mathbf{1 0 0} \boldsymbol{\mu M}$ & & GS50 $\boldsymbol{\mu M}$ & GS100 $\boldsymbol{\mu M}$ \\
\hline PC-SW & $76 \pm 19(\mathrm{SD})$ & 26 & & $1.52 \pm 0.15^{\dagger}$ & 1.92 \\
MCF7 & $77 \pm 28$ & $43 \pm 31$ & & 1.050 .23 & $2.11 \pm 0.39^{\dagger}$ \\
HT29 & $99 \pm 0$ & $88 \pm 16$ & & $1.03 \pm 0.04$ & $1.32 \pm 0.18$ \\
Bx-PC3 & $61 \pm 14$ & 26 & & $1.34 \pm 0.23$ & 1.40 \\
MIA PaCa-2 & $99 \pm 0$ & - & & $1.39 \pm 0.02^{\dagger}$ & - \\
\hline
\end{tabular}

${ }^{*}$ Control IR dose at $10 \%$ survival divided by the GS-treated IR dose at $10 \%$ survival \pm SEM. SD, standard deviation. Bx-PC3 and PC-Sw were done only once at the 100- $\mu \mathrm{M}$ GS dose. ${ }^{+} P$-value $<0.05$.

\section{p21 EXPRESSION}

Guggulsterone has been shown to induce the cyclin dependent kinase inhibitor, p21 $1^{\text {WAF/CIP1 }}$, leading to cell cycle blocks (Shishodia et al., 2007). The effects of IR and GS treatment on $\mathrm{p} 21^{\mathrm{WAF} / \mathrm{CIP} 1}$ induction were evaluated in two human tumor cell lines differing in their p53 status (MCF7, p53 normal; HT29 p53 mutated). In both cells lines $\mathrm{p} 21^{\mathrm{WAF} / \mathrm{CIP} 1}$ was up-regulated by either $50 \mu \mathrm{M}(10.6 \pm 0.2$-fold for the HT29 and 3.45 \pm 2.4 -fold for MCF7 cells) or $100 \mu \mathrm{M}$ GS (Figure 3). IR alone increased p $21^{\mathrm{WAF} / \mathrm{CIP} 1}$ in MCF7 cells, but not HT29 cells suggesting that GS must increase p $21^{\mathrm{WAF} / \mathrm{CIP1}}$ via a p53 and IR-independent mechanism.

\section{GS-MEDIATED RADIOSENSITIVITY}

The ability to interfere with cell cycle movement after IR exposure suggested that GS might alter the radiosensitivity of cells. Pilot studies initially carried out with PC-Sw cells indicated that $50 \mu \mathrm{M}$ GS incubation for times greater than $4 \mathrm{~h}$ increased cytotoxicity after a single 6 Gy IR dose $(6$ Gy alone $=0.278$ (relative survival), 6 Gy +4 h GS $=0.269,6 \mathrm{~Gy}+8 \mathrm{~h} \mathrm{GS}=0.152,6 \mathrm{~Gy}+18 \mathrm{~h}$ $\mathrm{GS}=0.133,6 \mathrm{~Gy}+24 \mathrm{~h} \mathrm{GS}=0.186)$. Subsequently, for full dose survival curves, cells were pre-treated for $24 \mathrm{~h}$ with GS (50 or $100 \mu \mathrm{M}$ final concentration) followed by IR. Studies with multiple

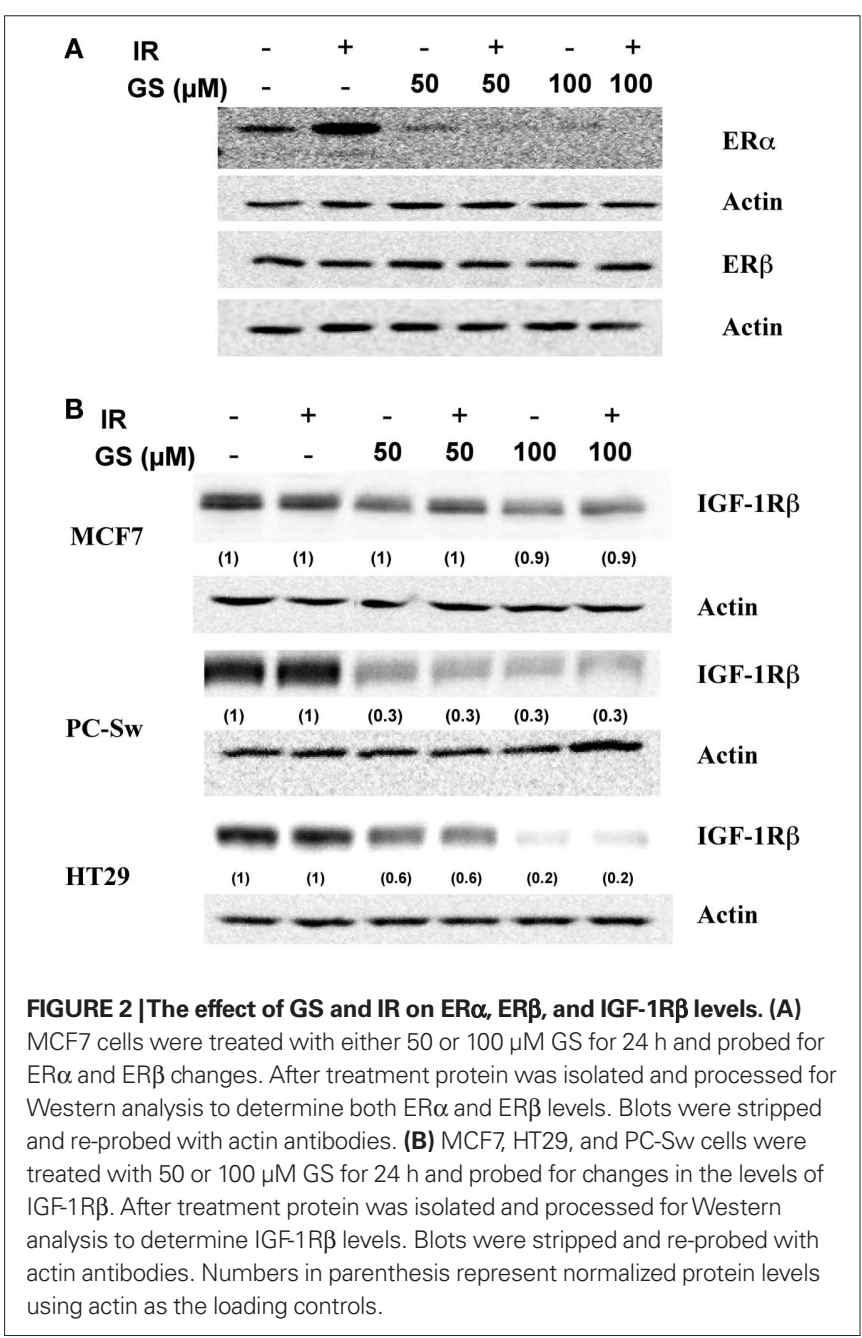


cancer cell lines (MCF7, HT29, Bx-PC3, DU145) showed enhanced radiosensitization after GS incubation (Figure 4; Table 1). As indicated, $50 \mu \mathrm{M}$ GS incubation was not cytotoxic alone but toxicity

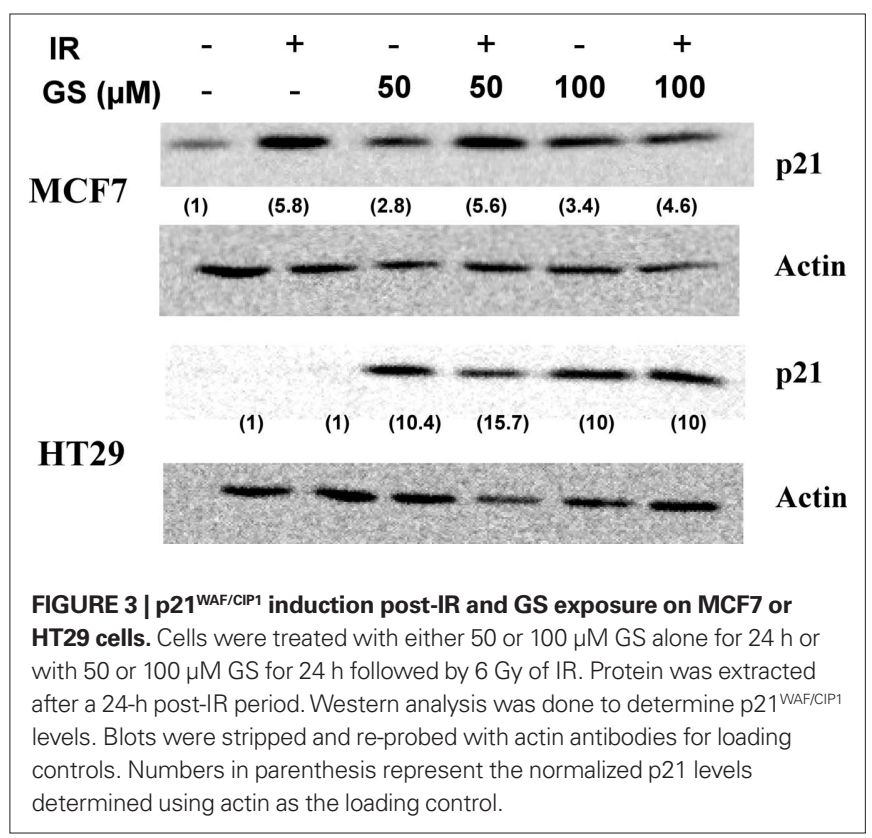

was increased significantly with $100 \mu \mathrm{m}$ GS incubation (Table 1). GS enhanced the radiosensitivity of the pancreatic cell lines at a concentration of $50 \mu \mathrm{M}$; whereas, the other cell lines did not show sensitization with this concentration. GS-mediated enhancement of radiosensitivity was observed in all the cell lines that were pre-treated with $100 \mu \mathrm{M}$ GS with DMFs ranging from 1.3 to 2.1 (Table 1).

\section{PHOSPHORYLATION OF H2AX}

To assess the effects of GS on IR-induced DNA damage and repair, phosphorylation of the H2AX protein $(\gamma \mathrm{H} 2 \mathrm{AX})$ was evaluated. Cells were pre-treated without or with 50 or $100 \mu \mathrm{M}$ GS, exposed to $6 \mathrm{~Gy}$, rinsed, and incubated in fresh medium. Figure 5A shows $\gamma \mathrm{H} 2 \mathrm{AX}$ levels as a function of time after IR in MCF7, HT29, or PC-Sw cells. All three cell lines exhibited increased $\gamma \mathrm{H} 2 \mathrm{AX}$ levels $1 \mathrm{~h}$ post-IR $(5.7 \pm 2.8,4.8$, and $5.4 \pm 0.8$, for MCF7, HT29, and PC-Sw cells, compared to control intensities, respectively). These levels were reduced at $24 \mathrm{~h}$ post-IR indicating repair. Pre-treatment using $50 \mu \mathrm{M}$ GS followed by IR did not change the kinetics of IR repair in any of the cell lines tested. However, $100 \mu \mathrm{M}$ GS pretreatment did inhibit DNA repair in the MCF7 and HT29 cells as the $\gamma \mathrm{H} 2 \mathrm{AX}$ remained elevated at $24 \mathrm{~h}$. GS treatment alone also induced $\gamma \mathrm{H} 2 \mathrm{AX}$ formation in the MCF7 $(2.4 \pm 0.4)$ and HT29 (5.1) cells as did $100 \mu \mathrm{M}$ GS, while $50 \mu \mathrm{M}$ GS treatment alone also increased $\gamma \mathrm{H} 2 \mathrm{AX}$ expression $(2.8 \pm 0.8)$ in the PC-Sw cells. Since
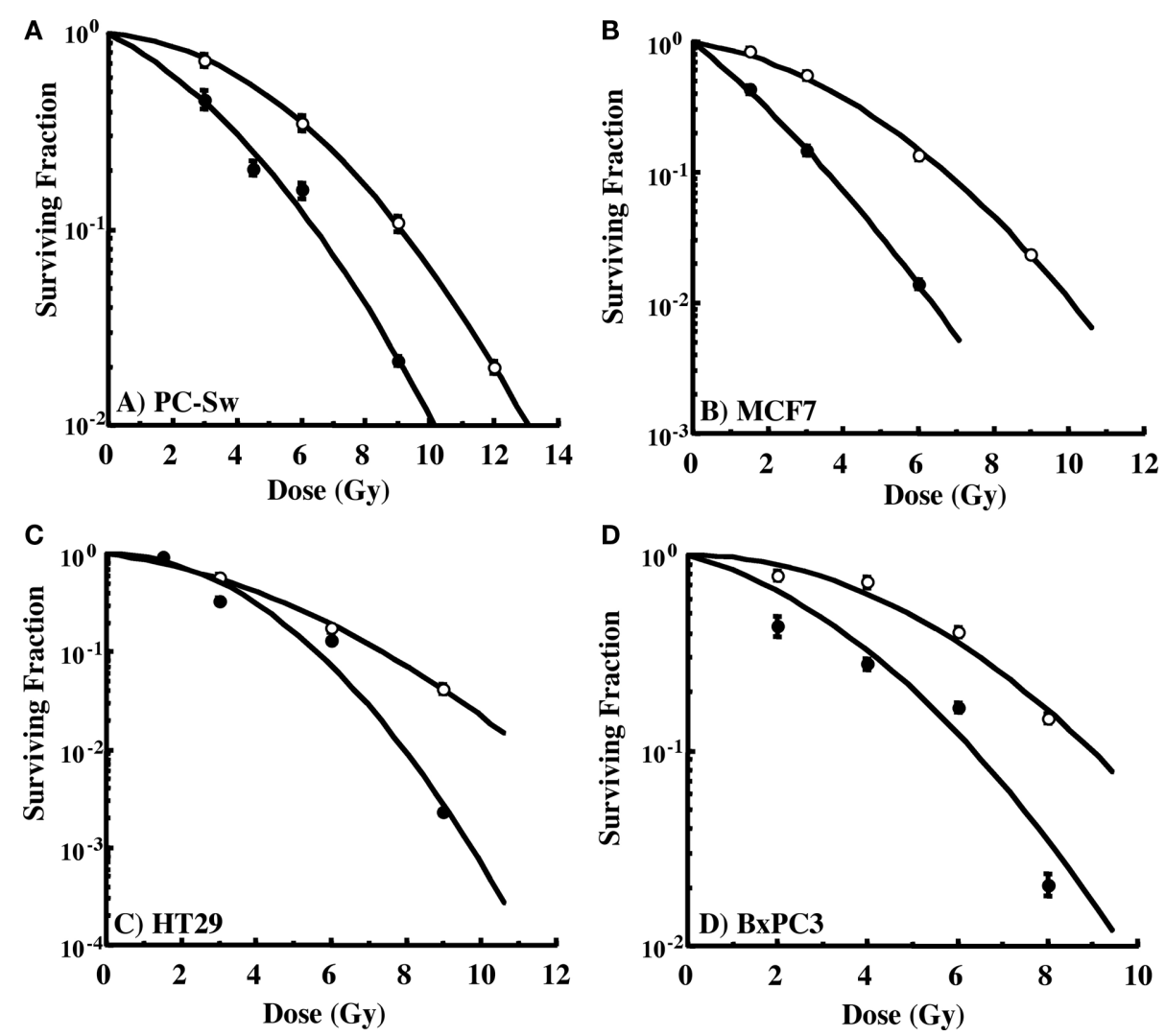

FIGURE 4 | Radiation cell survival curves for cells pre-incubated for $\mathbf{2 4} \mathrm{h}$ with or without $\mathbf{5 0}$ or $\mathbf{1 0 0} \mu \mathrm{M}$ GS and then exposed to varying doses of IR. (A) PC-Sw cells incubated with $50 \mu \mathrm{M}$ GS for $24 \mathrm{~h}$, (B) MCF7 cells incubated with $100 \mu \mathrm{M}$ GS (C) HT29 cells incubated with $100 \mu \mathrm{M}$ GS, (D) BX-PC3 cells incubated with $100 \mu$ M GS. GS cytotoxicity data and DMFs are shown in Table 1. 
GS treatment alone increased $\gamma \mathrm{H} 2 \mathrm{AX}$ levels, we examined whether the $\gamma \mathrm{H} 2 \mathrm{AX}$ levels were increased uniformly in all parts of the cell cycle of PC-Sw cells by using flow cytometry with simultaneous DNA and $\gamma \mathrm{H} 2 \mathrm{AX}$ labeling (Figures 5B,C). Compared to untreated controls, a 24-h $50 \mu \mathrm{M}$ GS treatment predominantly increased the $\gamma \mathrm{H} 2 \mathrm{AX}$ levels in S-phase cells.

Additional studies were conducted to determine if the H2AX $\gamma$ observed was accompanied by the formation of the cleaved PARP fragment. MCF7 cells showed a cleaved PARP fragment after $72 \mathrm{~h}$ incubation with $100 \mu \mathrm{M}$ GS while the HT29 cells showed damage by $48 \mathrm{~h}$ with $100 \mu \mathrm{M}$ incubation (data not shown). HT29 cells showed a small amount of cleaved PARP with $50 \mu \mathrm{M}$ GS only after $72 \mathrm{~h}$ GS incubation (data not shown). Neither the MCF7 nor the HT29 cells showed any cleaved PARP after $24 \mathrm{~h}$ GS incubation.

\section{NF-KB ACTIVATION}

It has been suggested that inactivation of NF- $\kappa B$ can enhance IR sensitization in cell lines (Deorukhkar and Krishnan, 2010). Since GS has been shown to suppress TNF-mediated NF- $\kappa B$ activation (Shishodia and Aggarwal, 2004) we examined if GS could alter $\mathrm{NF}-\kappa \mathrm{B}$ activation after radiation exposure. HT29 and PC-Sw cells were pre-treated with GS (50 and $100 \mu \mathrm{M})$ for $24 \mathrm{~h}$ alone, exposed to $10 \mathrm{~Gy}$ alone or incubated with GS and irradiated with $10 \mathrm{~Gy}$ and analyzed for NF- $\mathrm{KB}$ activation $3 \mathrm{~h}$ post-IR using a nuclear transactivation assay. Two different NF- $\mathrm{KB}$ subunits (p50 and p65) were

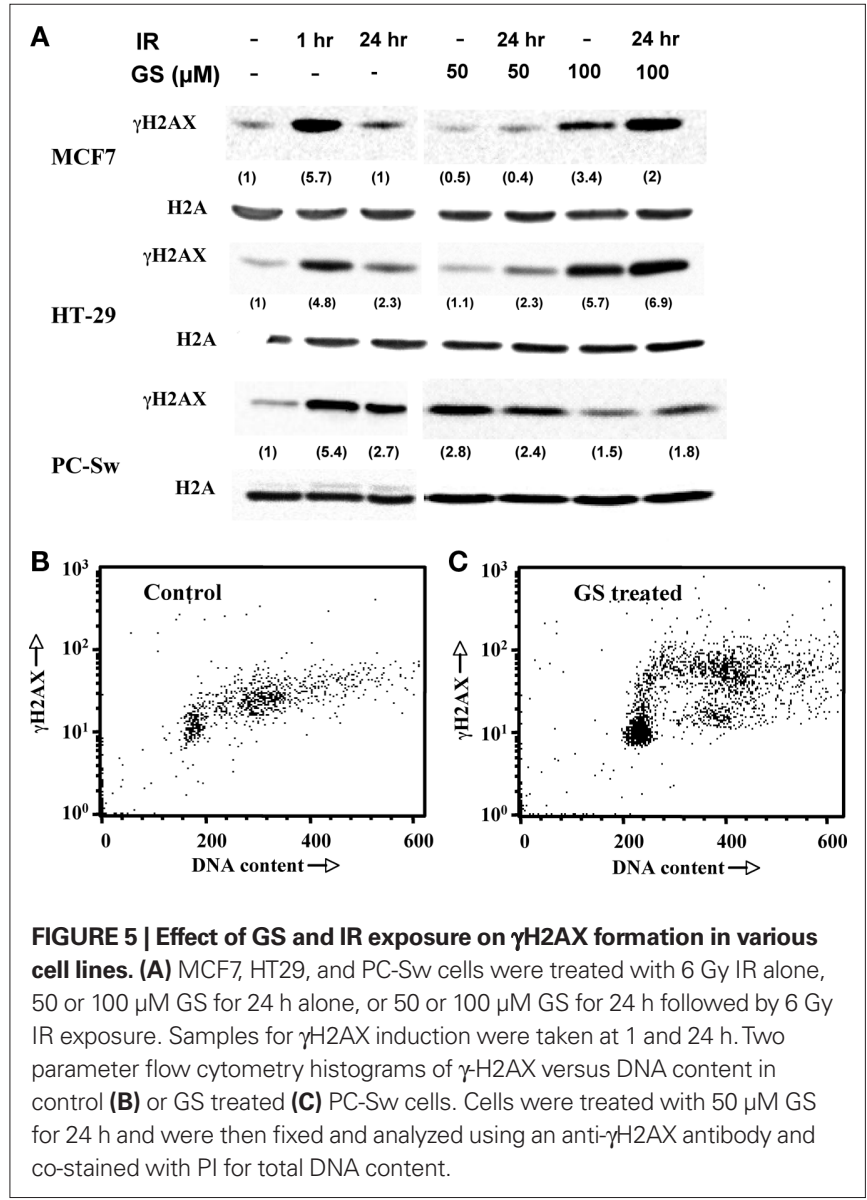

evaluated. NF- $\kappa \mathrm{B}$ activation after 10 Gy IR was observed in both cell lines since an increase in the levels of the p50 (26\% - HT29, $66 \%$ PC-Sw) and p65 (73\% - HT29, 24\% - PC-Sw) subunits was observed as shown in Figure 6. Constitutive NF- $\mathrm{KB}$ activity was reduced by GS treatment alone at $50 \mu \mathrm{M}$ (p65 30\% for PC-Sw, $8 \%$ for HT29; p50 19\% PC-Sw, 14\% for HT29) and $100 \mu \mathrm{M}$ (p65 33\% for PC-Sw, 19\% for HT29; p50 30\% for PC-Sw, $20 \%$ for HT29), although in some cases not significantly. After IR treatment GS significantly lowered the radiation induced NF- $\kappa \mathrm{B}$ activity for p65 (51-52\% for PC-Sw and 94-96\% for HT29) and p50 (90-95\% for PC-Sw and 52-57\% for HT29) in both cell lines.

\section{DISCUSSION}

Guggulsterone, a plant polyphenol, has several interesting biological properties that may have clinical applications. GS has been evaluated as an anti-hyperlipidemia agent with several clinical trials yielding inconclusive results (Szapary et al., 2003; Nohr et al., 2009). The anti-tumor activity of GS appears to be related to apoptotic mechanisms in a variety of tumor cell lines (Shishodia and Aggarwal, 2004; Samudio et al., 2005; Singh et al., 2005, 2007;

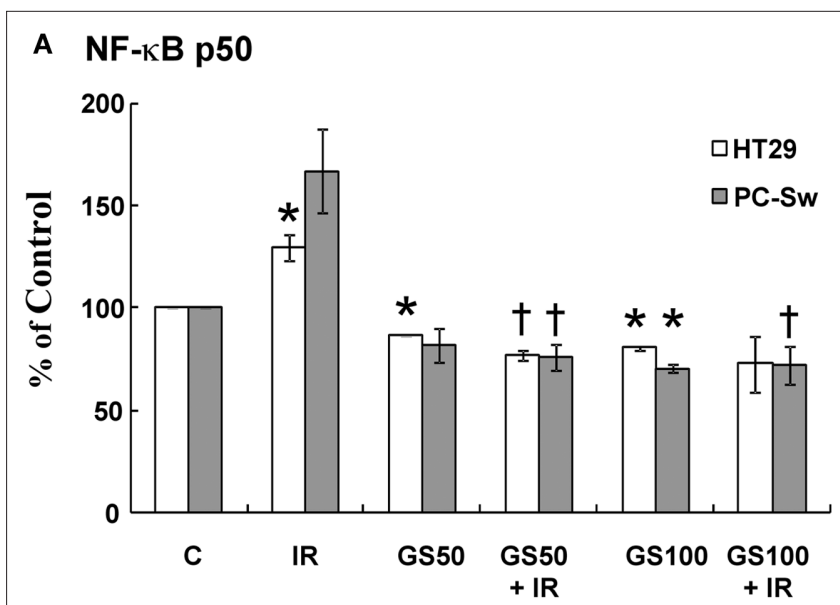

B $\quad \mathrm{NF}-\mathrm{kB}$ p65

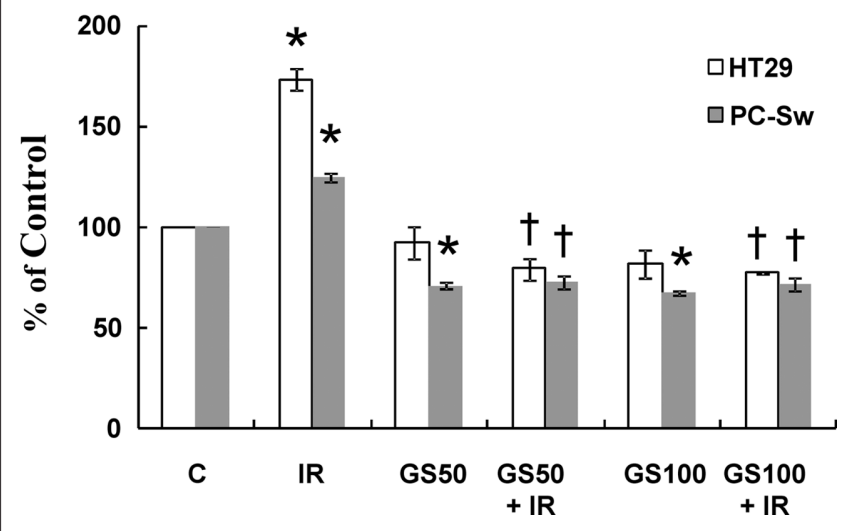

FIGURE 6 | NF-kB p50 and p65 activity in HT29 and PC-Sw cells measured after GS and IR exposure. Cells were pre-treated with GS (50 and $100 \mu \mathrm{M}$ ) for $24 \mathrm{~h}$ alone, exposed to $10 \mathrm{~Gy}$ alone, or incubated with GS and irradiated with $10 \mathrm{~Gy}$ and analyzed for NF-kB activation $3 \mathrm{~h}$ post-IR using a nuclear transactivation assay for NF-kB p50 (A) or NF-kB p65 (B) ${ }^{*} p$ values $<0.05$ compared to control, ${ }^{\dagger} p$ values compared to IR. 
Shishodia et al., 2007; An et al., 2009) and also in differentiating 3T3-L1 adipocytes (Yang et al., 2008), implicating consideration of GS in obesity. Our initial interest in GS came from studies showing that GS inhibits the activation of NF- $\mathrm{KB}$ a nuclear transcription factor that activates pro-survival pathways (Wang et al., 1996; Shishodia and Aggarwal, 2004). Since IR induces both NF- $\kappa B$ translocation and activation, we examined whether the inhibition of this pro-survival pathway by GS might lead to enhanced radiosensitivity via this mechanism. Support for this mechanism was found in the PC-Sw cells where $50 \mu \mathrm{M}$ GS incubation inhibited IR-induced $\mathrm{NF}-\kappa \mathrm{B}$ activation (Figure 6) and increased the radiosensitization in these cells (Figure 4A). However, it is unlikely that this is the only mechanism, since $50 \mu \mathrm{M}$ GS inhibited IR-induced NF- $\kappa B$ activation in the HT29 cells (Figure 6) but failed to enhance the radiosensitivity in these cells (Figure 4C). As previously reported, GS treatment not only inhibited IR-induced NF- $\kappa B$ activation, it also lowered constitutive NF- $\kappa \mathrm{B}$ activation in control untreated cells (Figure 6; Shishodia and Aggarwal, 2004).

Because the GS inhibition of NF- $\mathrm{KB}$ activation did not completely correlate with radiation sensitivity we also examined several other potential mechanisms of sensitization. First, given the propensity of GS to interact with several nuclear receptors such as PR, PXR, and ER $\alpha$ we examined if GS could interact with the IGF-1R $\beta$ receptor, a receptor linked with radiation sensitization (Macaulay et al., 2001). Expression of IGF-1R $\beta$ has been shown to confer radioresistance in cancer patients (Rocha et al., 1997). It has also been shown that inactivation of IGF-1R $\beta$ radiosensitizes human lung cancer cells (Cosaceanu et al., 2005). We observed in PC-Sw and HT29 cells, that either $50 \mu \mathrm{M}$ GS (in PC-Sw cells) or $100 \mu \mathrm{M}$ GS (in the HT29 cells) incubation did decrease the IGF-1R $\beta$ levels (Figure 2B), and this decrease correlated with the induction of radiosensitization seen in these cells (Figures 4A,C). However, IGF-1R $\beta$ in MCF7 cells showed minimal reduction after $100 \mu \mathrm{M}$ GS incubation (Figure 2B) although this concentration of GS did increase sensitization to IR (Figure 4B). Hence, it is possible that the GS reduction of IGF-1R $\beta$ may contribute to radiosensitization in certain cell types but in others the effect of GS on different receptors may be more important (such as ER $\alpha$ in MCF7 cells). The mechanism of IGF-1R $\beta$ receptor interaction in the repair of IR damage may be related to its effect on the repair related protein, ATM translocation (Macaulay et al., 2001; Peretz et al., 2001). Whether GS is altering this pathway remains to be determined.

Guggulsterone clearly interacts with steroidal receptors (Bovee et al., 2008) with the greatest activation being on the PR activity (Burris et al., 2005). It has been suggested that the direct interaction of GS with the PXR receptor is partially responsible for the activation of this receptor (Brobst et al., 2004). Our data shows that GS treatment down-regulates the ER $\alpha$ receptor in MCF7 cells. This is important because GS may have potential uses in estrogen positive tumors, which have developed resistance to the anti-estrogen, tamoxifen (Higgins and Stearns, 2009). Whether GS-mediated down-regulation of ER $\alpha$ plays a significant role in enhanced radiosensitivity will require further study. It is interesting to note that tamoxifen and estradiol have been shown to alter radiosensitivity of MCF7 cells suggesting that perturbation of the ER pathway can influence radiation response (Wazer et al., 1989; Paulsen et al., 1996).
Along with the down-regulation of the estrogen receptor GS inhibited cell growth in a variety of human tumor cell lines. Other groups have reported inhibition of cell growth either by MTT assay or ${ }^{3} \mathrm{H}$-thymidine uptake (Singh et al., 2005, 2007). Growth inhibition was reported to occur because of a G1/S or S-phase block. (Singh et al., 2007) However, Figures 1E-G shows that when PC-Sw cells are irradiated and followed for cell cycle changes that all parts of the cell cycle appear to be affected by GS as almost no movement is observed after GS + IR treatments. Thus, it appears that GS completely abrogates or at least greatly slows down cell cycle movement in each part of the cell cycle, including G1, S, and G2/M. One molecular target responsible for cell cycle blockage with GS incubation was the induction of the CDKI p $21^{\text {WAFI/CIP1 }}$ (Figure 3). Importantly, p2 $1^{\mathrm{WAF} / \mathrm{CIP} 1}$ induction also occurred in p53 mutated cells (HT29), which IR did not up-regulate (Figure 3), and hence, suggesting that GS up-regulates $\mathrm{p} 21^{\mathrm{WAF} / \mathrm{CIP} 1}$ by a $\mathrm{p} 53$ independent mechanism. Our cell cycle results do not entirely agree with earlier conclusions (Shishodia et al., 2007) that the block was in the S-phase part of the cell cycle in that GS incubation arrested cells in all parts of the cell cycle as clearly no movement was seen from any of the cell cycle compartments following a 6-Gy dose. Shishodia et al. (2007) did find that cdc2 (CDK1) and cyclin D1 were down-regulated, and since these two components of the cell cycle would be expected to impact both G1 and G2/M progression it would seem likely that movement throughout the cell cycle would be impacted.

Guggulsterone was a potent radiosensitizer at $100 \mu \mathrm{M}$ in all tumor cell lines studied (Figure 4; Table 1) while in several pancreas cell lines GS significantly increased radiosensitization using $50 \mu \mathrm{M}$ GS (Table 1). Interestingly, this effect was correlated with the induction of $\gamma \mathrm{H} 2 \mathrm{AX}$ phosphorylation as $50 \mu \mathrm{M}$ GS incubation increased $\gamma \mathrm{H} 2 \mathrm{AX}$ in the PC-Sw cells but not in the other cell lines (Figure 5). In addition, the other cell lines did show $\gamma \mathrm{H} 2 \mathrm{AX}$ phosphorylation when incubated with $100 \mu \mathrm{M}$ GS (Figure 5). Thus it appears that GS can induce double strand breaks (DSB's) in cells and this process could also be responsible for the increased radiosensitization observed. One area, which has received increased attention, is the formation of $\gamma \mathrm{H} 2 \mathrm{AX}$ foci when cells are exposed to treatments causing replication stress (Peretz et al., 2001; Chanoux et al., 2009). These conditions (usually with drugs) act by inhibiting the rapid repair of DSB's, which takes place during replication of the DNA during S-phase to relieve topological tension (Nitiss, 2009). Importantly, flow cytometry for $\gamma \mathrm{H} 2 \mathrm{AX}$ showed that GS-treated cells had $\gamma \mathrm{H} 2 \mathrm{AX}$ induced primarily in S-phase cells suggesting that GS was indeed acting to create sites of DSB's (Figures 5B,C). Thus, one mechanism of radiosensitization may be the production of DSB's in mid-to-late S-phase cells as this part of the cell cycle is considered to be the most resistant to IR exposure (Hall and Gaiaccia, 2006).

Another possible advantage of using GS as a clinical radiosensitizer has been reported detailing the selectivity of GS for tumor vs normal cells. Earlier studies have showed that a normal prostate epithelial cell line is resistant to growth inhibition and apoptosis caused by GS when compared to prostate tumor cells (Singh et al., 2005). We examined cleaved PARP after $100 \mu \mathrm{M}$ GS incubation in both MCF7 and HT29 cells and found that cleaved PARP was observed only after $48 \mathrm{~h}$ in HT29 cells and $72 \mathrm{~h}$ GS incubation 
in MCF7 cells. Since radiation studies were done using a $24 \mathrm{~h}$ GS incubation, the activation of apoptosis did not appear to be a major pathway for sensitization; however, additional studies are needed to fully examine this mechanism and if GS may interact with normal tissue differently than with the tumor cells examined in this study.

It is interesting to note that the GS concentrations that are effective in bringing about radiosensitization are in the range of the doses, which were used to impact on the inflammatory, apoptotic, and cell cycle pathways (Shishodia and Aggarwal, 2004; Shishodia

\section{REFERENCES}

Albright, N. (1987). Computer programs for the analysis of cellular survival data. Radiat. Res. 112, 331-340.

An, M. J., Cheon, J. H., Kim, S. W., Kim, E. S., Kim, T. I., and Kim, W. H. (2009). Guggulsterone induces apoptosis in colon cancer cells and inhibits tumor growth in murine colorectal cancer xenografts. Cancer Lett. 279, 93-100.

Bovee, T. F., Schoonen, W. G., Hamers, A. R., Bento, M. J., and Peijnenburg, A. A. (2008). Screening of synthetic and plant-derived compounds for (anti) estrogenic and (anti)androgenic activities. Anal. Bioanal. Chem. 390, 1111-1119.

Brobst, D. E., Ding, X., Creech, K. L., Goodwin, B., Kelley, B., and Staudinger,J.L. (2004). Guggulsterone activates multiple nuclear receptors and induces CYP3A gene expression through the pregnane $\mathrm{X}$ receptor. J. Pharmacol. Exp. Ther. 310, 528-535.

Burris, T. P., Montrose, C., Houck, K. A., Osborne, H. E., Bocchinfuso, W. P., Yaden, B. C., Cheng, C. C., Zink, R. W., Barr, R. J., Hepler, C. D., Krishnan, V., Bullock, H.A., Burris, L. L., Galvin, R. J., Bramlett, K., and Stayrook, K. R. (2005). The hypolipidemic natural product guggulsterone is a promiscuous steroid receptor ligand. Mol. Pharmacol. 67, 948-954.

Chander, R., Khanna, A. K., and Kaapor, N. K. (1996). Lipid lowering activity of guggulsterone from Commiphora mukul in hyperlipaemic rats. Phytother. Res. 10, 508-511.

Chanoux, R. A., Yin, B., Urtishak, K. A., Asare, A., Bassing, C. H., and Brown, E. J. (2009). ATR and H2AX cooperate in maintaining genome stability under replication stress. J. Biol. Chem. 284, 5994-6003.

Chautard, E., Loubeau, G., Tchirkov, A., Chassagne, J., Vermot-Desroches, C., Morel, L., and Verrelle, P. (2010). Akt signaling pathway: a target for radiosensitizing human malignant glioma. Neuro Oncol. 12, 434-443.

Cosaceanu, D., Carapancea, M., Castro, J., Ekedahl, J., Kanter, L., Lewensohn, R., and Dricu, A. (2005). Modulation of response to radiation of human lung cancer cells following insulin-like growth factor 1 receptor inactivation. Cancer Lett. 222, 173-181.

Deorukhkar, A., and Krishnan, S. (2010). Targeting inflammatory pathways for tumor radiosensitization. Biochem. Pharmacol. 80, 1904-1914.

Dixit, V. P., Joshi, S., Sinha, R., Bharvava, S. K., and Varma, M. (1980). Hypolipidemic activity of guggal resin (Commiphora mukul) and garlic (Allium sativum Linn.) in dogs (Canis familiaris) and monkeys (Presbytis entellus entellus Dufresne). Biochem. Exp. Biol. 16, 421-424.

Hait, W. N., and Hambley, T. W. (2009). Targeted cancer therapeutics. Cancer Res. 69, 1263-1267; discussion 1267.

Hall, E. J., and Gaiaccia, A. J. (2006). Radiology for the Radiologist. Philadelphia: Lippincott Williams \& Wilkins.

Hambley, T. W., and Hait, W. N. (2009). Is anticancer drug development heading in the right direction? Cancer Res. 69, 1259-1262.

Higgins, M. J., and Stearns, V. (2009). Understanding resistance to tamoxifen in hormone receptor-positive breast cancer. Clin. Chem. 55, 1453-1455.

Li, N., and Karin, M. (1998). Ionizing radiation and short wavelength UV activate NF-kappaB through two distinct mechanisms. Proc. Natl. Acad. Sci. U.S.A. 95, 13012-13017.

Liebmann, J., Cook, J.A., Fisher, J., Teague, studies of Taxol as a radiation sensitizer in human tumor cells. J. Natl. Cancer Inst. 86, 441-446. Kwon, K. B., and Park, B. H. (2008). Guggulsterone, a plant sterol, inhibits NF-kappaB activation and protects pancreatic beta cells from cytokine toxicity. Mol. Cell. Endocrinol. 289, 49-59.

Ma, W. W., and Adjei, A. A. (2009). Novel agents on the horizon for cancer therapy. CA Cancer J. Clin. 59, 111-137.

Macaulay, V. M., Salisbury, A. J., Bohula, E. A., Playford, M. P., Smorodinsky, N. I. and Shiloh, Y.(2001). Downregulation of the type 1 insulin-like growth factor D., and Mitchell, J. B. (1994). In vitro

Lv, N., Song, M. Y., Kim, E. K., Park, J. W.,

et al., 2007; An et al., 2009). The ability of GS to modulate ER $\alpha$ and other membrane receptors suggest that it might be a useful drug to alter disease conditions where these receptors are thought to impact. The ability of GS to modulate radiosensitivity in human cancer cell lines warrants further study.

\section{ACKNOWLEDGMENTS}

This research was supported by the Intramural Research Program of the Center of Cancer Research, National Cancer Institute, National Institutes of Health.

receptor in mouse melanoma cells is associated with enhanced radiosensitivity and impaired activation of Atm kinase. Oncogene 20, 4029-4040.

Nitiss, J. L. (2009). DNA topoisomerase II and its growing repertoire of biological functions. Nat. Rev. Cancer 9, 327-337.

Nityanand, S., Srivastava, J.S., and Asthana, O. P. (1989). Clinical trials with gugulipid. A new hypolipidaemic agent. J. Assoc. Physicians India 37, 323-328.

Nohr, L. A., Rasmussen, L. B., and Straand, J. (2009). Resin from the mukul myrrh tree, guggul, can it be used for treating hypercholesterolemia? A randomized, controlled study. Complement. Ther. Med. 17, 16-22.

Paulsen, G. H., Strickert, T., Marthinsen, A. B., and Lundgren, S. (1996). Changes in radiation sensitivity and steroid receptor content induced by hormonal agents and ionizing radiation in breast cancer cells in vitro. Acto Oncol. 35, 1011-1019.

Peretz, S., Jensen, R., Baserga, R., and Glazer, P. M. (2001). ATM-dependent expression of the insulin-like growth factor-I receptor in a pathway regulating radiation response. Proc. Natl. Acad. Sci. U.S.A. 98, 1676-1681.

Rocha, R. L., Hilsenbeck, S. G., Jackson, J. G., Vandenberg, C. L., Weng, C., Lee, A. V., and Yee, D. (1997). Insulin-like growth factor binding protein-3 and insulin receptor substrate- 1 in breast cancer: correlation with clinical parameters and disease-free survival. Clin. Cancer Res. 3, 103-109.

Samudio, I., Konopleva, M., Safe, S., Mcqueen, T., and Andreeff, M. (2005). Guggulsterones induce apoptosis and differentiation in acute myeloid leukemia: identification of isomer-specific antileukemic activities of the pregnadienedione structure. Mol. Cancer Ther. 4, 1982-1992.

Shishodia, S., and Aggarwal, B. B. (2004) Guggulsterone inhibits NF-kappaB and IkappaBalpha kinase activation, suppresses expression of anti-apoptotic gene products, and enhances apoptosis. J. Biol. Chem. 279, 47148-47158.

Shishodia, S., Harikumar, K. B., Dass, S., Ramawat, K. G., and Aggarwal,
B. B. (2008). The guggul for chronic diseases: ancient medicine, modern targets. Anticancer Res. 28, 3647-3664.

Shishodia, S., Sethi, G., Ahn, K. S., and Aggarwal, B. B. (2007). Guggulsterone inhibits tumor cell proliferation, induces S-phase arrest, and promotes apoptosis through activation of c-Jun $\mathrm{N}$-terminal kinase, suppression of Akt pathway, and downregulation of antiapoptotic gene products. Biochem. Pharmacol. 74, 118-130.

Singh, S. V., Choi, S., Zeng, Y., Hahm, E. R., and Xiao, D. (2007). Guggulsteroneinduced apoptosis in human prostate cancer cells is caused by reactive oxygen intermediate dependent activation of c-Jun NH2-terminal kinase. Cancer Res. 67, 7439-7449.

Singh, S. V., Zeng, Y., Xiao, D., Vogel, V. G., Nelson, J. B., Dhir, R., and Tripathi, Y. B. (2005). Caspase-dependent apoptosis induction by guggulsterone, a constituent of ayurvedic medicinal plant Commiphora mukul, in PC-3 human prostate cancer cells is mediated by Bax and Bak. Mol. Cancer Ther. 4, 1747-1754

Szapary, P. O., Wolfe, M. L., Bloedon, L. T., Cucchiara, A. J., Dermarderosian, A. H., Cirigliano, M. D., and Rader, D. J. (2003). Guggulipid for the treatment of hypercholesterolemia: a randomized controlled trial. JAMA 290, 765-772.

Urizar, N. L., Liverman, A. B., Dodds, D. T., Silva, F. V., Ordentlich, P., Yan, Y., Gonzalez, F. J., Heyman, R. A., Mangelsdorf, D. J., and Moore, D. D. (2002). A natural product that lowers cholesterol as an antagonist ligand for FXR. Science 296, 1703-1706.

Wang, C. Y., Mayo, M. W., and Baldwin, A. S. Jr. (1996). TNF- and cancer therapy-induced apoptosis: potentiation by inhibition of NF-kappaB. Science 274, 784-787.

Wazer, D. E., Tercilla, O. F., Lin, P. S., and Schmidt-Ullrich, R. (1989). Modulation in the radiosensitivity of MCF-7 human breast carcinoma cells by $17 \mathrm{~B}$-estradiol and tamoxifen. Br. J. Radiol. 62, 1079-1083.

Xiao, D., and Singh, S. V. (2008). z-Guggulsterone, a constituent of ayurvedic medicinal plant Commiphora 
mukul, inhibits angiogenesis in vitro and in vivo. Mol. Cancer Ther. 7, 171-180.

Yang, J. Y., Della-Fera, M. A., Rayalam, S., Ambati, S., Hartzell, D. L., Park, H. J., and Baile, C. A. (2008). Enhanced inhibition of adipogenesis and induction of apoptosis in 3T3-L1 adipocytes with combinations of resveratrol and quercetin. Life Sci. 82, 1032-1039.
Conflict of Interest Statement: The authors declare that the research was conducted in the absence of any commercial or financial relationships that could be construed as a potential conflict of interest.

Received: 12 May 2011; accepted: 05 July 2011; published online: 21 July 2011.
Citation: Choudhuri R, DeGraff W, Gamson J, Mitchell JB and Cook JA (2011) Guggulsterone-mediated enhancement of radiosensitivity in human tumor cell lines. Front. Oncol. 1:19. doi: 10.3389/ fonc.2011.00019

This article was submitted to Frontiers in Radiation Oncology, a specialty of Frontiers in Oncology.
Copyright (c) 2011 Choudhuri, DeGraff, Gamson, Mitchell and Cook. This is an open-access article subject to a nonexclusive license between the authors and Frontiers Media SA, which permits use, distribution and reproduction in other forums, provided the original authors and source are credited and other Frontiers conditions are complied with. 